\title{
Benzo(a)pyrene-albumin adducts in humans exposed to polycyclic aromatic hydrocarbons in an industrial area of Poland
}

\author{
E H Kure, Å Andreassen, S Øvrebø, E Grzybowska, Z Fiala, M Strózyk, M Chorazy, \\ A Haugen
}

\begin{abstract}
Objectives-The interaction of benzo(a)pyrene with serum albumin was measured in an attempt to identify the actual exposure and to evaluate albumin adduct measurements as biomarkers for exposure monitoring.
\end{abstract}

Methods - Benzo(a)pyrene-diol-epoxide (BPDE)-albumin adducts were measured by competitive enzyme linked immunosorbent assay (ELISA) in plasma of coke oven plant workers from three plants and from people living in a highly industrialised area of Silesia in Poland. Due to the high air concentrations of polycyclic aromatic hydrocarbons (PAHs) in this area, a control group was selected from a rural non-industrialised area in Poland. Breathing zone air measurements of PAHs were collected from some of the participants.

Results-Coke oven plant workers and non-occupationally exposed people had similar concentrations of albumin adducts whereas the rural controls were significantly lower $(2.74 \mathrm{fmol}$ adducts/ $\mu \mathrm{g}$ albumin (SEM 0.124)). The mean concentration of BPDE-albumin adduct in plasma of both the occupational and the environmental groups were significantly higher in the summer samples $(4.34 \mathrm{fmol}$ adducts/ $\mu$ galbumin (SEM 0.335) and 4.55 fmol adducts/ $\mu$ g albumin (SEM 0.296), respectively) than in the winter samples (3.06 fmol adducts/ $\mu$ g albumin (SEM $0.187)$ and $3.04 \mathrm{fmol}$ adducts/ $\mu \mathrm{g}$ albumin (SEM 0.184), respectively) even though the air measurements showed higher concentrations of PAHs in the winter. The statistical analysis did not show any effects of air exposures on concentrations of BPDE-albumin adduct.

Conclusions-A multiple regression analysis of the measured concentrations of BPDE-albumin adducts for all the groups, during both seasons, indicates that occupational exposures do not contribute significantly to the formation of adducts. In general, the concentrations of albumin adducts found vary within relatively small limits for the two seasons and between the various groups of participants. No extreme differences were found.

(Occup Environ Med 1997;54:662-666)
Keywords: albumin adducts; polycyclic aromatic hydrocarbons; enzyme linked immunosorbent assay

Polycyclic aromatic hydrocarbons (PAHs) are among the most prevalent air pollutants in Silesia, Poland. ${ }^{2}$ The main source of exposure to PAHs is the use of black coal for industrial purposes and domestic heating causing air concentrations of PAHs to be almost 10 times higher than in western Europe. ${ }^{2}$ Humans are exposed to PAHs through the respiratory and digestive tract and the skin. In most settings the exposure to PAHs from food and tobacco is estimated to be much higher than from air and water. ${ }^{3}$ Thus, human exposure to PAHs is difficult to assess from air measurements alone. As serum albumin is synthesised in hepatocytes where microsomal oxidation takes place it is likely that highly reactive electrophiles of PAHs may react with serum albumin. Studies in rodents exposed to PAHs have shown that DNA adducts are formed in several tissues. ${ }^{4}$ However, the composition and persistence of the DNA adducts may differ in the various tissues. ${ }^{6-9}$ As genotoxic carcinogens form covalent bonds with DNA as well as with proteins some studies have also compared the degree of covalent binding of metabolites of benzo(a)pyrene with DNA and proteins. ${ }^{10}$ Contrasting results have been reported. ${ }^{11}$ The assessment of benzo(a)pyrene-diol-epoxide (BPDE)-albumin adducts is considered as a potential marker of exposure to PAHs. There are few studies on measurements of BPDE-albumin adducts in populations. ${ }^{12-16}$

The primary aim of the study was to identify the relevance of using BPDE-albumin adducts as a measure of air exposure to PAHs. The concentration of BPDE-albumin adduct, measured in plasma by enzyme linked immunosorbent assay (ELISA), of occupationally and environmentally exposed people living in Silesia were compared with concentrations of adduct measured in a control group selected from a rural non-industralised area of Poland. Breathing zone air measurements of PAHs were collected from some of the exposed groups. ${ }^{17}$ The general notion is that air concentrations of PAHs influence the concentration of DNA adducts in exposed people and this may also apply to albumin adducts. ${ }^{10} 18$

The secondary aim of the study was to investigate any seasonal effects on the concentration of BPDE-albumin adducts. Recent data on DNA adducts in lymphocytes of people 
Table 1 Characterisation of the study groups

\begin{tabular}{llllll}
\hline & \multicolumn{2}{l}{ Age $(y)$} & & \\
\cline { 2 - 3 } Location & Mean & Range & $S D$ & \multirow{2}{*}{ Smokers (\%) } & Subjects (n) \\
\hline Coke oven plants: & & & & & \\
$\quad$ Plant B & 45.1 & $30-57$ & 8.51 & 33.3 & 15 \\
$\quad$ Plant D & 46.7 & $30-59$ & 8.51 & 78.6 & 14 \\
$\quad$ Plant E & 38.1 & $22-59$ & 10.89 & 76.7 & 30 \\
$\quad$ All plants & 41.9 & $22-59$ & 10.37 & 66.1 & 59 \\
Environmentally exposed groups: & & & & & 13 \\
$\quad$ Gliwice & 38.8 & $24-57$ & 10.96 & 84.6 & 23 \\
$\quad$ Bytom & 38.6 & $19-55$ & 12.14 & 56.5 & 12 \\
$\quad$ Swietochlowice & 51.0 & $17-76$ & 22.03 & 16.7 & 48 \\
$\quad$ All groups & 41.7 & $17-76$ & 15.57 & 54.2 & 45 \\
Rural controls: & 34.8 & $22-57$ & 9.37 & 62.2 & \\
$\quad$ Biala Podlaska & & & &
\end{tabular}

Table 2 Linear regression models for the analysis of concentrations of BPDE-albumin adducts (dependent variable) in occupationally exposed, environmentally exposed, and rural control subjects

\begin{tabular}{llllr}
\hline Model & Variables in model & Regression coefficient & (95\% CI) & P values \\
\hline 1 & Control & -1.7239 & $(-2.3093$ to -1.1385$)$ & $<0.001$ \\
& Smoking & 0.7643 & $(0.1837$ to 1.3450$)$ & 0.01 \\
& Constant & 3.9877 & $(3.4890$ to 4.4864$)$ & $<0.001$ \\
2 & Season & -1.4359 & $(-1.9132$ to -0.9586$)$ & $<0.001$ \\
& Age & -0.0192 & $(-0.0368$ to 0.0015$)$ & 0.03 \\
& Constant & 5.2744 & $(4.4240$ to 6.1247$)$ & $<0.001$ \\
3 & Season & -1.3399 & $(-2.0385$ to -0.6413$)$ & $<0.001$ \\
& Age & -0.0298 & $\left(-0.0605\right.$ to $\left.8.39 \times 10^{-4}\right)$ & 0.06 \\
& Constant & -5.6321 & $(4.1993$ to 7.0649$)$ & $<0.001$ \\
4 & Season & -1.0941 & $(-1.9997$ to -0.18841$)$ & $<0.02$ \\
& Constant & 4.1682 & $(3.4904$ to 4.8459$)$ & $<0.001$ \\
\hline
\end{tabular}

^ Season $=$ winter.

living in this region ${ }^{19}{ }^{20}$ have shown a seasonal effect which has been linked to higher air exposure of PAHs in the winter season. It is of interest to investigate whether this also applies to BPDE-albumin adducts.

This study contributes to determination of the relevance of the use of albumin adducts to assess the total exposure to PAHs in a human population and the contribution of exposures from air.

\section{Materials and methods}

STUDY SUBJECTS AND SAMPLE COLLECTION

The subjects were male workers from three coke oven plants in the Silesian area and environmentally exposed people living in close vicinity to the plants. The members of the rural control group lived in Biala Podlaska, an area of Poland without heavy industry. Each participant completed a questionnaire on lifestyle factors (including smoking), medical history, age, and workplace description. Blood was collected by venepuncture in heparinised sterile tubes. Plasma was separated from the whole blood and transported frozen. Samples of PAHs in the breathing zone air of the workers were collected during the same day as the blood sampling took place. Personal sampling of PAHs of non-occupationally exposed people was performed in one of the Silesian environmental groups (Gliwice). For practical reasons, the other two environmental groups and the rural controls were not measured by personal sampling. However, stationary air sampling was performed in Biala Podlaska during the summer season and blood samples were available for the rural controls only for this season. Except for these limitations, air and blood were sampled twice; winter (February 1992) and summer (September 1992). Rural control blood samples were collected only in the summer of 1993. If exposures to airborne PAHs from general heating affected the concentrations of albumin adduct it would be expected that adduct concentrations in the summer would be lower than in the winter and therefore be a better control group if there was only the option of sampling once. Table 1 shows the characteristics of the study groups.

\section{ANALYSIS OF BENZO(a)PYRENE-ALBUMIN} ADDUCTS IN PLASMA

Globulins were precipitated from plasma with saturated ammonium sulphate. After removal by centrifugation, albumin was precipitated by acidification of the supernatant with acetic acid and redissolved in Tris-EDTA buffer $(10 \mathrm{mM}$ Tris/1.0 mM EDTA , pH 8.0). ${ }^{13}$ The concentration of albumin was measured by the Lowry assay $^{21}$ before acid hydrolysis. The digest was applied to a prewet C18-Sep-Pak cartridge (Waters, Milford, ML). The cartridge was washed with $5 \%$ methanol $(5 \mathrm{ml})$ to remove small peptides and amino acids. The $\mathrm{PAH}$ metabolites were eluted with $80 \%$ methanol (5 $\mathrm{ml}$ ), evaporated to $1 \mathrm{ml}$ in a vacuum, and assayed directly with competitive ELISA with monoclonal antibody $8 \mathrm{E} 11$ as described elsewhere. ${ }^{1422}{ }^{23}$ Briefly, microtitre plates were coated with BPDE modified calf thymus DNA in phosphate buffered saline (PBS) by drying. The plates were washed with PBS-Tween and then incubated with $2 \%$ fetal calf serum in PBS. A standard curve was made of serial dilutions of benzo(a)pyrene tetrols from 0.2-220 $\mathrm{nM}(50 \mu \mathrm{l}$ each) and mixed with $50 \mu \mathrm{l}$ antibody $8 \mathrm{E} 11$ (diluted 1:20 000), before addition to the wells. After incubation overnight at $4^{\circ} \mathrm{C}$ and washing of the plates, $100 \mu \mathrm{l}$ goat anti-mouse IgG conjugated with alkaline phosphatase (diluted 1:750) was added and incubated for 1.5 hours. Finally, $100 \mu \mathrm{l} p$-nitrophenyl phosphate in $1 \mathrm{M}$ diethanolamine ( $\mathrm{pH} \mathrm{8.6)}$ was added. After incubation the absorbance at 405 $\mathrm{nm}$ was measured with a Titertek Multiscan Pluss microplate reader. Samples were analysed twice with triplicate wells. The values are the mean of all assays and expressed as fmol equivalents of BPDE-I adducts due to a significant cross reactivity with several PAH metabolites. ${ }^{14}$

\section{MEASUREMENTS OF PAH EXPOSURE}

For the assessment of exposure to PAHs 12 compounds were selected as outlined by the National Institute of Occupational Safety and Health (fluoranthene, pyrene, benz(a)anthracene, chrysene/triphenylene, benzo(e)pyrene, benzo(a)pyrene, indeno( $1,2,3-\mathrm{cd})$ pyrene, dibenz(a,h)-anthracene, benzo(ghi)perylene, and benzofluoranthenes (two isomers)). ${ }^{24}$

Sampling of particulate PAH was performed with Casella AFC 123 (Casella, London, England) and DuPont S2500 (DuPont, Largo, Florida) pumps at a flow rate of 21 air per minute for six to eight hours as previously described. ${ }^{17}$ The standard $25 \mathrm{~mm}$ sampling cassette Nucleopore filter (Pleasanton, California) was made of polyethene with carbon black 
Table 3 Mean (SEM) concentrations of BPDE-albumin adducts for the three groups

\begin{tabular}{|c|c|c|c|c|c|c|}
\hline \multirow[b]{3}{*}{ Location } & \multicolumn{6}{|c|}{ BPDE-albumin adducts (fmol adducts/ $/ \mathrm{g}$ albumin) } \\
\hline & \multicolumn{3}{|c|}{ February 92} & \multicolumn{3}{|c|}{ September 92} \\
\hline & Mean & (SEM) & $n$ & Mean & (SEM) & $n$ \\
\hline Combined groups plants & 3.06 & $(0.187)$ & 59 & 4.34 & $(0.335)$ & 38 \\
\hline Combined environmental groups & 3.04 & $(0.184)$ & 48 & 4.55 & $(0.296)$ & 36 \\
\hline Rural controls ${ }^{\star}$ & - & $(-)$ & - & 2.74 & $(0.124)$ & 45 \\
\hline
\end{tabular}

^September 1993.

Table 4 PAH and benzo(a)pyrene air measurements $\left(\mu \mathrm{g} / \mathrm{m}^{3}\right)$ from personal sampling *

\begin{tabular}{|c|c|c|c|c|c|c|c|c|}
\hline \multirow[b]{3}{*}{ Location } & \multicolumn{4}{|c|}{ September 92} & \multicolumn{4}{|c|}{ February 92} \\
\hline & \multicolumn{2}{|l|}{$P A H$} & \multicolumn{2}{|l|}{$B(a) P$} & \multicolumn{2}{|l|}{$P A H$} & \multicolumn{2}{|l|}{$B(a) P$} \\
\hline & Mean & (SEM) & Mean & (SEM) & Mean & (SEM) & Mean & $(S E M)$ \\
\hline $\begin{array}{l}\text { Combined plants } \\
\text { Environmental, }\end{array}$ & 4.40 & $(1.75)$ & 0.58 & $(0.24)$ & 7.03 & $(2.10)$ & 0.83 & $(0.25)$ \\
\hline Gliwice & 0.13 & $(0.07)$ & 0.01 & $(0.01)$ & 0.28 & $(0.08)$ & 0.03 & $(0.01)$ \\
\hline Biala Podlaska† & - & - & 0.02 & - & - & - & - & - \\
\hline
\end{tabular}

$\star$ Concentrations of PAH and benzo(a)pyrene (B(a)P) have previously been published by Ovrebo et al..$^{17}$

† Stationary sampling.
The last analysis focused on the effect of air measurements (PAHs and benzo(a)pyrene), and group on the concentration of BPDEalbumin adduct in the environmental subgroup of Gliwice and the occupational group working in plant $\mathrm{D}$ for the two seasons. The subset of the data was adjusted for any confounding effects of smoking and age. Table 2 model 4 shows the final model. A detailed statistical analysis on air exposures of these groups has previously been published by $\emptyset v r e b ø$ et al. ${ }^{17}$

\section{Results}

Table 3 shows the mean concentrations of BPDE-albumin adducts in plasma collected during summer and winter seasons of coke oven plant workers, environmentally exposed people (living in the vicinity of the plants), and rural controls (from Biala Podlaska).

The mean concentration of BPDE-albumin adducts of the rural controls was $1.72 \mathrm{fmol}$ adducts/ $\mu \mathrm{g}$ albumin lower than for the other two groups for the summer season having controlled for smoking status $(P<0.001$, table 2 model 1). The environmental groups had concentrations of BPDE-albumin adducts similar to those of coke oven plant workers in both the summer and the winter season. However, season had a significant effect on the mean concentration of BPDE-albumin adducts (1.44 fmol adducts / $\mu \mathrm{g}$ albumin higher in the summer samples than in the winter samples after controlling for age $(\mathrm{P}<0.001$, table 2 , model 2)).

Air measurements of PAHs and benzo(a)pyrene presented in this study have previously been published by $\emptyset$ vrebø et al (table 4). ${ }^{17}$ The data have been used in this study for comparing the air concentrations of PAHs and benzo(a)pyrene with the concentrations of BPDEalbumin adducts of the occupationally exposed groups for the two seasons. The statistical analysis did not show any effects of air exposures on the concentrations of BPDEalbumin adducts. Although the air concentrations of PAHs and benzo(a)pyrene were much higher in the winter season; the concentrations of adducts showed the opposite effect with lower concentrations in the winter. The only significant effect found in the analysis was for season. The concentrations of BPDE-albumin adduct for the occupationally exposed groups were on average $1.34 \mathrm{fmol}$ adducts / $\mu \mathrm{g}$ albumin higher in the summer samples than in the winter samples after controlling for age $(P<0.001$, table 2 model 3 ). A seasonal effect only was found when analysing effects of air measurements of PAHs and benzo(a)pyrene on the concentrations of BPDE-albumin adducts in the environmental subgroup of Gliwice and the occupational group working on the plant in this area for the two seasons. The mean concentration of BPDE-albumin adducts was $1.09 \mathrm{fmol}$ adducts $/ \mu \mathrm{g}$ albumin higher in the summer than in the winter samples $(P<0.02$, table 2 model 4).

The background concentrations of albumin adducts in the rural controls are relatively high and it is suspected that they cannot be explained by the air measurements alone as was adjusted for any confounding effects final regression model. 
stationary monitoring of environmental air in Biala Podlaska, September 1993 was only 20.4 $\mathrm{ng} / \mathrm{m} 3$ benzo(a)pyrene. ${ }^{17}$

In general, the concentrations of BPDEalbumin adducts found vary within relatively small limits for the two seasons and between the various groups of participants. No extreme differences were found.

\section{Discussion}

In this study environmental controls and coke oven plant workers had similar concentrations of BPDE-albumin adducts whereas the rural controls had significantly lower concentrations. Although the rural control samples were collected a year later than the samples from the exposed groups this would not be expected to be of any importance to the study as the concentrations only reflect relatively short term exposures related to the half life of albumin. Our results from the linear regression analysis show that the concentrations of albumin adduct are not influenced significantly by air concentrations of PAHs. The measured air concentrations of PAHs were higher in the winter than in the summer with a wide range in exposures between the different people participating in the study. The measurements were based on one sampling of each person on one particular day (mean six to eight hours). The measurements should for this reason only be viewed as point estimates and the group means do not reflect the true means of these populations. The results from the regression analysis could be influenced by this. However, this does not explain the fact that the mean concentrations of BPDE-albumin adducts in both the workers and the environmental groups were significantly higher in the summer samples than in the winter samples. Other sources could contribute to the higher concentrations in the summer season.

This also contrasts with what was found on groups from this region analysed by postlabelling and ELISA on PAH-DNA adducts in lymphocytes. ${ }^{19}{ }^{20}$ However, no seasonal variation was found in DNA adducts of granulocytes measured by the ${ }^{32} \mathrm{P}$ postlabelling assay ${ }^{19}$ and ELISA (unpublished results) in coke oven plant workers and environmental groups. This is probably due to the short lifespan of granulocytes. ${ }^{25}$

Hemminki et al also found that the patterns of hydrophobic adducts in DNA of lymphocytes were similar in coke oven plant workers and environmental groups but not in rural controls. ${ }^{26}$ They concluded that people living in the vicinity of the plants were highly exposed to PAHs and that the concentrations of aromatic adducts in white blood cell DNA did not linearly relate to ambient air concentrations of PAH. They suggested that other sources might contribute to the high background concentrations.

The concentrations of albumin adducts reflect integrated exposure over a period of time related to the half life of albumin (20-25 days). The lymphocytes are thought to have an active DNA repair system. ${ }^{19}$ The kinetics of albumin adducts are linear whereas lym- phocytes may have dose dependent non-linear kinetics as well as cell turnover. The decrease in concentrations of DNA adduct of lymphocytes indicate that they have an active DNA repair with a half life of one to two months which is only slightly longer than for albumin. ${ }^{19}$ Therefore, other sources of exposure may contribute to the concentration of albumin adducts in these people especially during summer. The PAHs in the environment may contaminate locally grown vegetables and fruits. ${ }^{27}{ }^{28}$ The inhabitants of Silesia tend to supplement their diet with locally grown produce during the summer season and this may contribute to the higher concentrations of albumin adducts found in the summer. In the general population, the oral intake of PAH may be higher than the inhaled. ${ }^{28}{ }^{29}$ The effects of PAH ingested in the diet on concentrations of DNA adducts in lymphocytes are not well known. ${ }^{26}$ Some studies have shown an increased concentration of DNA adducts in humans after ingestion of charcoal broiled meat but the data are limited. $^{29}$ As albumin is synthesised in the hepatocytes where microsomal oxidation takes place highly reactive electrophiles may react with albumin. Perhaps PAH through diet may contribute more than airborne PAH to the concentration of protein adducts than to that of lymphocytic DNA adducts. ${ }^{10} 18$

In summary, albumin adducts as a biomarker of exposure may be a sensitive end point measure for PAHs when various routes of absorption contribute to the total body burden.

This study was supported by a grant from EU project EV5V-CT 92-0213. ZF was supported by a grant from the Norwegian Scientific Council. We thank Dr RM Santella for the antibody $8 \mathrm{E} 11$ producing hybridoma cell line.

1 Motykiewicz G, Cimander B, Szeliga A, Tkocz A, Chorazy $M$. Mutagenic activity of complex air pollutants in Silesia. In: Vaino H, Sorsa M, McMichael AJ, eds. Complex mixtures and cancer risk. Lyon: IARC, 1990:261-8.

2 Chorazy M, Szeliga J, Strozyk M, Cimander B. Ambient ai pollutants in Upper Silesia: partial chemical composition and biological activity. Environ Health Perspect 1994;102 61-6.

3 Hemminki K, Pershagen G. Cancer risk of air polution: epidemiological evidence. Environ Health Perspect 1994;102. 187-92.

4 Ginsberg GL, Atherholt TB. Transport of DNA-adducting metabolites in mouse serum following benzo(a)pyrene metabolites in mouse serum following be

5 Ginsberg GL, Atherholt B. DNA adduct formation in mouse tissues in relation to serum levels of benzo(a)pyrene-diol-epoxide after injection of benzo(a)pyrene or the diol-epoxide. Cancer Res 1990;50:1 189-94.

6 Stowers SJ, Anderson MW. Formation and persistence of benzo(a)pyrene metabolite-DNA adducts. Environ Health Perspect 1985;62:31-9.

7 van Schooten FJ, Hillebrand MJX, Scherer E, den Engelse L, Kriek E. Immunocytochemical visualization of DNA adducts in mouse tissues and human white blood cells foladducts in mouse tissues and human white blood cells following treatment with benzo(a)pyrene or its diol epoxide.

8 Molliere M, Foth H, Kahl R, Kahl F. Comparison of benzo(a)pyrene metabolism in isolated perfused rat lung and liver. Arch Toxicol 1987;60:270-7.

9 Ross J, Nelson G, Kligerman A, et al. Formation and persistence of novel benzo(a)pyrene adducts in rat lung, liver, and peripheral blood lymphocytes DNA. Cancer Res 1990;50:5088-94.

10 Skipper PL, Tannenbaum R. Protein adducts in the molecular dosimetry of chemical carcinogens. Carcinogen esis 1990;11:507-18.

11 Weyand EH, Bevan DR. Covalent binding of benzo(a)pyrene to macromolecules in lung and liver of rats following intratracheal instillation. Cancer Lett 1987;36:149-59.

12 Hemminki K, Zang LF, Kruger J, Autrup H, Tornquist M, Norbeck H-E. Exposure of bus and taxi drivers to urban air pollutants as measured by DNA and protein adducts. Toxicol Lett 1994;72:171-4. 
13 Sherson D, Sabro P, Sigsgaard T, Johansen F, Autrup H. Biological monitoring of foundry workers exposed to polycyclic aromatic hydrocarbons. Br F Ind Med 1990;47:448 53.

14 Lee MB, Baoyun Y, Herbert R, Hemminki K, Perera FP, Santella RM. Immunologic measurement of polycyclic aromatic hydrocarbon-albumin adducts in foundry workers and roofers. Scand 7 Work Environ Health 1991;17:190-4.

15 Omland Ø, Sherson D, Hansen AM, Sigsgaard T, Autrup $\mathrm{H}$, Overgaard E. Exposure of iron foundry workers to polycyclic aromatic hydrocarbons: benzo(a)pyrene-albumin cyclic aromatic hydrocarbons: benzo(a)pyrene-albumin adducts and 1-hydroxypyrene as biom

16 Blondin O, Viau C. Benzo(a)pyrene-blood protein adducts in wild woodchucks used as biological sentinels of environmental polycyclic aromatic hydrocarbons contamination Arch Environ Contam Toxicol 1992;23:310-5.

17 Øvrebø S, Fjeldstad PE, Grzybowska E, Kure EH, Chorazy $M$, Haugen A. Biological monitoring of polycyclic aromatic hydrocarbon exposure in a highly polluted area of Poland. Environ Health Perspect 1995;103:838-43.

18 Tannenbaum RS, Skipper PL, Wishnok JS, Stillwell WG, Day BW, Taghizadeh K. Characterization of various classes of protein adducts. Environ Health Perspect 1993;99:51-5.

19 Grzybowska E, Hemminki K, Szeliga J, Chorazy M Seasonal variation of aromatic DNA adducts in human lymphocytes and granulocytes. Carcinogenesis 1993;14: lymphocy

20 Perera FP, Hemminki K, Gryzbowska E, et al. Molecular and genetic damage in humans from environmental pollution in Poland. Nature 1992;360:256-8.
21 Lowry OH, Rosebrough A, Farr AL, Randall RJ. Protein measurement with the folin phenol reagent. $f$ Biol Chem 1951;193:265-75.

22 Santella RM, Lin CD, Cleveland WL, Weinstein IB. Monoclonal antibodies to DNA modified by a benzo(a)pyrene diol epoxide. Carcinogenesis 1984;5:373-7.

23 Santella RM, Lin CD, Dharmaraja N. Monoclonal antibodies to a benzo(a)pyrene diolepoxide modified protein. Carcinogenesis 1986;7:441-4.

24 National Institute of Occupational Safety and Health Manual of analytical methods. 3rd ed. Cincinnati, $\mathrm{OH}$ : NIOSH, 1985. (NIOSH Publ No 84-100.)

25 Savela K, Hemminki K. DNA adducts in lymphocytes and granulocytes of smokers and non-smokers detected by the ${ }^{2} \mathrm{P}$-postlabelling assay. Carcinogenesis 1991;12:503-8.

26 Hemminki K, Grzybowska E, Chorazy M, et al. DNA adducts in humans environmentally exposed to aromatic compounds in an industrial area of Poland. Carcinogenesis 1990;11:1229-31.

27 International Agency for Research on Cancer. IARC monographs on the evaluation of the carcinogenic risk of chemicals to humans. Polynuclear aromatic compounds, part 1, chemical, environmental and experimental data. Lyon: IARC, 1983.

28 World Health Organisation. Polynuclear aromatic hydrocarbons (PAH), In: Air quality guidelines for Europe, Copenhagen: WHO, 1987:105-17.

29 dell'Omo M, Lauwerys MD. Adducts to macromolecules in the biological monitoring of workers exposed to polycyclic aromatic hydrocarbons. Crit Rev Toxicol 1993;23:111-26.

\section{Rejected manuscripts}

From February 1994, authors whose submitted articles are rejected will be advised of the decision and one copy of the article, together with any reviewer's comments, will be returned to them. The fournal will destroy remaining copies of the article but correspondence and reviewers' comments will be kept. 